\title{
Occurrence and distribution of king eiders Somateria spectabilis and common eiders $S$. mollissima at Disko, West Greenland
}

\author{
OLE FRIMER
}

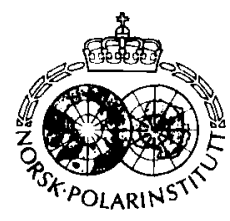

Frimer, O. 1993: Occurrence and distribution of king eiders Somateria spectabilis and common eiders $\boldsymbol{S}$. mollissima at Disko, West Grcenland. Polar Research 12(2), 111-116.

King eiders and common eiders were recorded at Disko Island, West Greenland, in the period 1989-1993. Both species occur year-round in the area, although in low numbers during the period of extensive icecover January-April. In May and the first half of June, large numbers of king and common eiders on spring migration stage along the western coast of Disko. In the autumn (August-October) an estimated 15,40020.100 king eiders undergo prebasic moult in the area, with the highest concentrations in the fjords and bays of western Disko and along the coast of southeast Disko. This estimate indicates that a recent population decline may have taken place. Only two female common eiders with ducklings were recorded during the study period. In the period July-September an estimated 3,200-4,800 male common eiders undergo prebasic moult in the area, mainly at the archipelago of Kitsissut and in the outer fjords and bays of western Disko Island.

Ole Frimer, Zoological Museum, University of Copenhagen, Universitetsparken 15, DK-2100 Copenhagen $\emptyset$, Denmark.

\section{Introduction}

King eiders Somateria spectabilis and common eiders $S$. mollissima borealis occur commonly in the Disko Bay region, central West Greenland, during the ice-free period (Salomonsen 1967). In spring, both eider species pass Disko on their way to the breeding grounds (Abraham \& Finney 1986). The common eider breeds in very low numbers on Disko Island. In July and August the small resident population is accompanied by postbreeding male common eiders (Frimer in press), presumably from breeding grounds in West Greenland north of Disko and/or from northeast Canada, who undergo prebasic moult here. Between mid-July and early September large numbers of post-breeding king eiders from the eastern and central Canadian Arctic and northwest Greenland arrive in the area and undergo prebasic moult here along with a number of immatures and adult non-breeders which have spent the summer south of the potential breeding range (Salomonsen 1968; Frimer in press). Both eider populations spend the winter in southwest Greenland (Salomonsen 1967, 1968).

Apart from a few counts of king eiders in Aqa- jarua, easternmost Disko (Salomonsen 1967; Boertmann 1979), no systematical ground or aerial surveys of eiders have hitherto been made in the area. Salomonsen (1968) assumed that some 100,000 king eiders undergo prebasic moult in central West Greenland, with the highest concentrations in the Disko Bay region.

In the summer of 1989 I took part in a bird survey on eastern Disko Island (Frimer \& Nielsen 1990 ), and in the period June 1990-May 1993 I stayed on Disko Island. During this period I made systematic and occasional year-round observations on the occurrence of eiders at Disko. This paper summarizes these observations.

\section{Study area and methods}

Observations were made along the entire coast of Disko Island and at the archipelago of Kitsissut in the western Disko Bay (Fig. 1).

The sea surrounding Disko Island is ice-covered from mid-January to mid-April, whereas the fjords and bays may be ice-covered from November to mid or late June. Surveys from vessels 


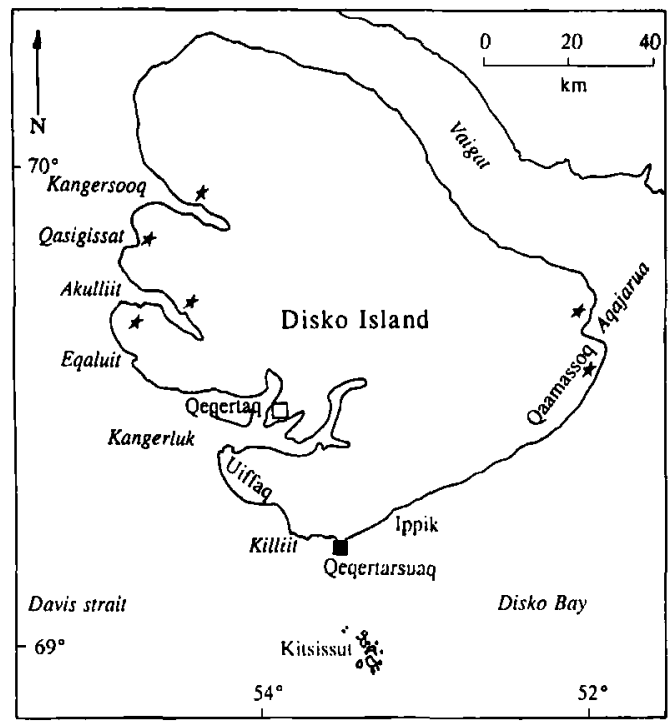

Fig. 1. Disko Island, showing location of places mentioned in the text. ${ }^{*}=$ camp site; $\square=$ town; $\square=$ village (bygd)

were possible in the western parts of Disko from mid-May, while in the northern and eastern parts, surveying was prevented by large amounts of drift ice until early June (early July in some areas).

Observations were carried out from the Arctic Stations research vessel PORSILD and from the coast. A total of about 350 single observations of eiders were made during the study period. The following surveys and observations provide the data for this paper:

\section{May-October}

Most western and southern parts of the study area were surveyed 6-10 times during 1990-1992. The northwestern coast was surveyed once each year in August, and the northeastern coast on 24 August 1990. Additional observations were carried out from the coast near the town of Qeqertarsuaq and from camps positioned on western Disko between Akulliit and Kangersooq and at Aqajarua, easternmost Disko (Fig. 1). Further details are given together with the results.

\section{November-April}

Non-regular, but frequent, observations were made from the coast between Ippik and Kangerluk. Observations were, however, few between late November and mid-January, due to continuous darkness.

\section{Results}

\section{Aqajarua (Mudderbugten)}

On 11 and 12 June 1990, approximately 570 king eiders and 30-35 common eiders were present in the bay. In late June 1989, 1990 and 1991, between 200 and 250 king eiders and between 50 and 500 common eiders were counted here each year. In the period July-September 1990, 1991 and 1992 a maximum of about 400 eiders (mainly king eiders) were observed in the bay each year.

\section{Qaamassoq (Flakkerhuk)}

During four surveys carried out between midJune and mid-July 1990, 1991 and 1992, 88-200 eiders were observed along the coast of Qaamassoq each year, with about $80 \%$ being king eiders. The area was surveyed four times in the moulting season: In late July-early August 1990 and 1991, 3-400 eiders (mainly king eiders) were observed each year; and in early September 1992, a minimum of 3,100 king eiders were present here. On 23 October 1992, i.e., after the moulting season, about 10,000 king eiders were observed along this coast, in flocks of up to about 3,000 birds.

\section{The south coast of Disko}

In spring, flocks of up to about 200 king eiders and 75 common eiders may stage and feed along the coast between Qeqertarsuaq and Qaamassoq, while later in the season most observed flocks were by-passers. In the period of extensive icecover, flocks of up to about 25 eiders occasionally occur at temporarily open patches.

\section{Kitsissut (Kronprinsens Ejlands)}

Flocks of common eiders were recorded here on several occasions between mid-May and late August of 1990 and 1991, the maximum number being $350-400$ individuals on 11 July 1990 . King eiders were seen in numbers of up to about 40 individuals. 


\section{The Killiit (Fortunebay)-Uiffaq (Blåfjeld) coast}

Between mid-May and mid-June 1991 and 1992, 335-470 eiders of both species occurred along this coast. On 22 June 1992, about 300 king eiders were observed along Uiffaq. Between late June and mid-September 1990, 1991 and 1992, a maximum of 75 eiders of both species were recorded in the area. A single common eider was observed at Killiit in February.

\section{Kangerluk (Diskofjord)}

Between mid-May and mid-June 1990, 1991 and 1992 , numbers ranging from 500 to 2,500 eiders of both species were recorded along the edge of the fjord ice of Kangerluk. On 17 June 1992, a total of about 3,000 eiders (almost exclusively king eiders) were observed here.

In early July 1992, about 200 king eiders were recorded at Qeqertaq, and about 220 common eiders were observed along the north coast of the outer fjord. Small flocks of both species were regularly seen in the inner fjord in July.

In late August 1991, about 500 king eiders were observed in the innermost parts of the fjord, and about 400 king eiders were present at Qeqertaq, with several flocks elsewhere in the area. In December 1992 some hundred king eiders were observed along the edge of the fjord ice at the mouth of Kangerluk.

\section{Eqaluit (Nordre Laksebugt)}

In May and early June 1991, up to about 200 eiders were recorded in Eqaluit. The area was only visited twice in the moulting season (September 1990 and late July 1991), when a maximum of 35 eiders of both species were observed within the bay, with additional small flocks along the outer coast immediately north and south of the bay.

\section{Akullit (Mellemfjord)}

On 17 May approximately 3,000 eiders were observed here, with about $50 \%$ being common eiders. Numbers decreased gradually during the following month, and on 18 June about 100 eiders of both species were present here.

A single female common eider with three ducklings was recorded in early September 1992 in the inner fjord.
In late July 560 king eiders were present in the fjord, and by mid-September numbers had increased to an estimated $2,200-2,400$ individual (Frimer in press).

On 8 August 1991 a flock of more than 200 common eiders was observed in Akulliit. In midAugust 1992 about 120 common eiders were present at a small bay near the mouth of the fjord, with small flocks elsewhere in the area.

\section{Qasigissat}

On 19 June 1991 about 700 king eiders were staging along the ice-edge of the bay Qasigissat. In early July 1992, 160 king eiders and 47 common eiders were counted within the bay. In late July 1990 and 1991, 600-800 moulting common eiders and $70-80$ king eiders were present at Qasigissat, making Qasigissat the most important moulting area for common eiders at Disko. In mid-September 1992 at least 500 king eiders were moulting within the bay, with several additional flocks along the outer coast immediately north and south of the bay.

\section{Kangersooq (Nordfjord)}

On 25 May 1991, a total of 101 king eiders and 16 common eiders were recorded moving northwards $10-25 \mathrm{~km}$ offshore, following the edge of the Davis Strait pack ice.

On 20 July 1991, about 300 king eiders and 200 common eiders were present in Kangersooq, and on 2 August 1992 about 400 king eiders and 325 common eiders were counted in the fjord. In mid-September 1990 and 1991 more than 1,000 individuals occurred in the inner parts of the fjord, with several flocks elsewhere in the area.

\section{Northwest Disko}

In late August 1990, about 2,500 eiders (almost exclusively king eiders) were recorded here, while in mid-August 1991 and 1992 only about 200 king eiders were observed along this coastline each year.

A female common eider with two newly hatched ducklings was recorded at a coastal lagoon on 18 August 1991.

\section{The Vaigat coast}

A total of 200-250 eiders were recorded along this coastline on 24 August 1990. Most of these 
birds were moving southwards, suggesting that this area is not used for moulting by large numbers of eiders.

\section{Sex ratios}

The sex ratio of king and common eiders was recorded in a number of sample flocks during the study period. Of 383 king eiders sexed in May and June, $48 \%$ were females. The sex ratio in king eiders at Disko, during the period JulySeptember, has been treated in Frimer (in press): Females made up an estimated $33 \%$ of the population in July, $24 \%$ in mid-August and $48 \%$ in mid-September.

Of 122 common eiders sexed between early May and mid-June, $39 \%$ were females. In the breeding season, mid-June-August, females comprised less than $1 \%$ of the recorded common eiders (see also Frimer \& Nielsen 1990; Frimer in press). No observations on the sex ratio of common eiders were made after August.

\section{Discussion}

\section{The spring migration}

Both eider species arrive at Disko from midApril, when the sea ice breaks up. In May and the first half of June, large numbers of king and common eiders on spring migration stage at the ice-edge of the fjords and bays of western Disko Island; for example, on 17 May 1991 a total of about 6,000 eiders were counted between Killiit and Akulliit. By mid-June the majority of the eiders have left the area, the common eiders apparently about a week earlier than the king eiders.

\section{The moult migration}

Less than a month after the last pre-breeding king eiders have left Disko, the first post-breeders return to the area to undergo prebasic moult here. The males arrive between mid-July and midAugust, and the females between mid-August and early September (Salomonsen 1968; Frimer in press). Consequently, the male:female ratio in king eiders shifts from about $1: 1$ in spring, to about $3: 1$ in mid-August, and back to about $1: 1$ in mid-September.

Considering that only two female common eiders with ducklings were recorded in the study period, most of the comparatively large numbers of males present in the area from July are probably post-breeders from breeding grounds in West Greenland north of Disko and/or from Northeast Canada (see Salomonsen 1967; Abraham \& Finney 1986). The low proportion of female common eiders present in the area in the breeding season indicates that immature and non-breeding female common eiders do not use the Disko Bay area for moulting, unlike those of king eiders (Frimer in press).

\section{Autumn distribution and population sizes}

The most important moulting areas for king eiders were found to be the fjords and bays of western Disko and along the coast of Qaamassoq (Fig. 2A), but small groups and single individuals may occur anywhere along the coasts of Disko Island in the moulting season. The highest concentrations of moulting common eiders were recorded at the archipelago of Kitsissut and in the outer bays and fjords of western Disko (Fig. 2B).

Based on numbers recorded in the study area in the summer and autumn of the years 19901992, the total autumn populations of king eiders (September) and male common eiders (JulyAugust) at Disko are estimated to be 15,400 20,100 and $3,200-4,800$ individuals, respectively (Table 1). As no data on the sex ratio of common eiders is available after August, it is not known whether post-breeding female common eiders from breeding grounds outside the study area undergo prebasic moult at Disko.

Although the timing of moult in both species varies with sex and age (Cramp \& Simmons 1977; Frimer in press), the population turnover of eiders in the moulting season is probably low, because the majority of the eiders do not leave the area until some time after the period of prebasic moult (Salomonsen 1967). Judged from the few observations made in the late autumn, after the period of prebasic moult, eiders congregate at the mouth of the fjords when these become ice-covered, and particularly in the eastern Disko Bay.

There is no doubt that the summer and autumn population of king eiders at Disko is not as numerous at present as in the 1960s and 1970s. In Aqajarua, Boertmann (1979) counted 2,800 king eiders in June 1975 and 2,500 in July 1976, and Salomonsen (1967) reported about 30,000 king eiders at Aqajarua in August. 

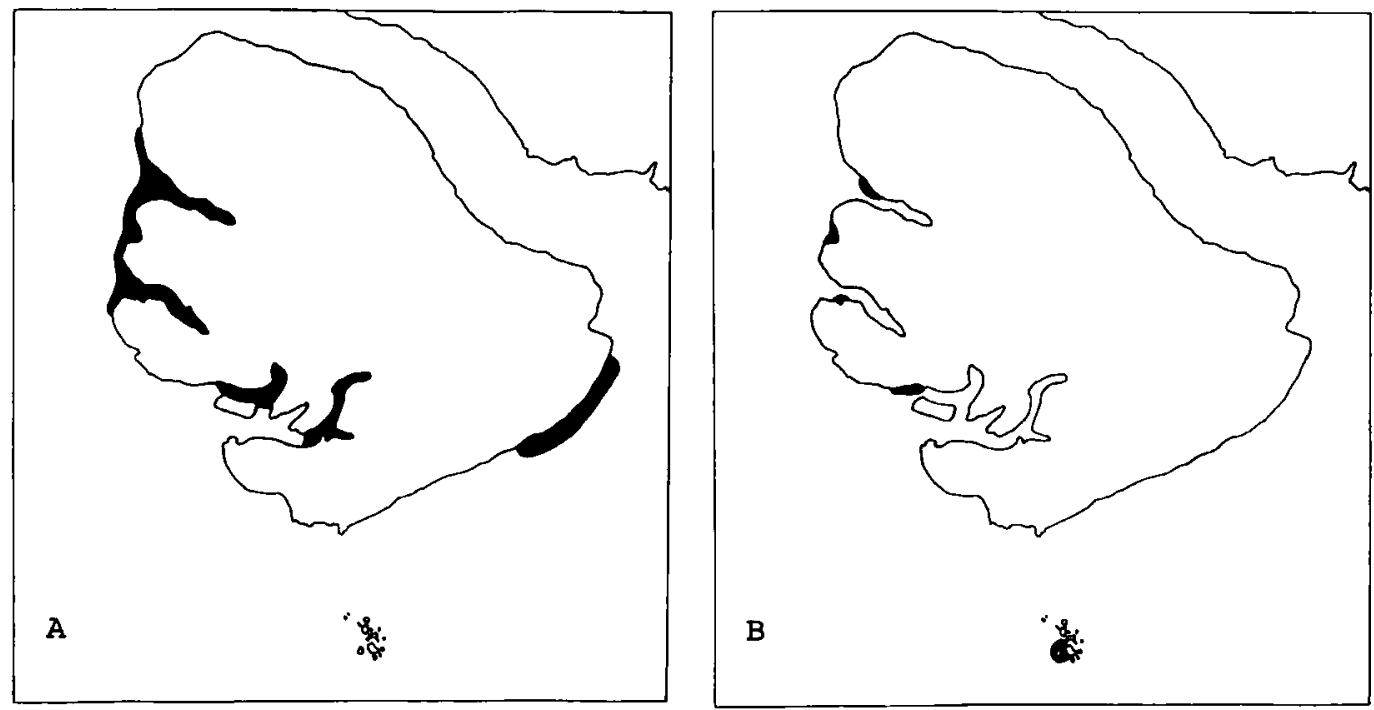

Fig. 2. Important moulting areas for king ciders (A) and common eiders (B) at Disko, based on observations made during 1990 1992.

King eiders shed their flight feathers simultaneously and become flightless for about three weeks (Salomonsen 1990). In this period they become extremely shy and highly vulnerable to predation. At Disko, moulting king eiders feed primarily on soft bottom molluscs, with Mya truncata, Serripes groenlandicus and Cardium ciliatum together comprising more than $80 \%$ of the diet by wet weight (Frimer in press). In recent years, trawlers from the town of Ilulissat, situated at the eastern Disko Bay, have been dredging clams Chlamys islandicus in Aqajarua in the summer and autumn. The consequent damage to the bottom fauna and the disturbance caused by these trawlers may explain the low numbers of king eiders in Aqajarua in this study. Whether the reduced numbers reflect a decline in the population as a whole or only a redistribution is open to dispute. No attempts have been made to estimate the king eider population(s) in question

Table 1. Estimated numbers of king eiders and male common eiders moulting at Disko; based on observations made during 19901992.

\begin{tabular}{|c|c|c|c|}
\hline Locality & $\begin{array}{l}\text { King eider } \\
\text { (September) }\end{array}$ & $\begin{array}{l}\text { Common cider } \\
\text { (July-August) }\end{array}$ & Comments \\
\hline Aq̨ajarua & $300-500$ & $100-200$ & \\
\hline Qaamassoq & $3,500-4,000$ & $100-200$ & \\
\hline South coast & $200-300$ & $100-200$ & Assumed \\
\hline Kitsissut & $100-200$ & $600-800$ & \\
\hline Killiit-Uiffaq & $100-200$ & $50-100$ & \\
\hline Kangerluk & $2,500-3,000$ & $4(0)-6(x)$ & \\
\hline Eqaluit & $200-400$ & $50-100$ & Including outer coastal area \\
\hline Akulliit & $2,500-3,000$ & $400-600$ & Including outer coastal area \\
\hline Qasigissat & $1,000-1,500$ & $80(1-1.000$ & Including outer coastal area \\
\hline Kangersooq & $2,500-3.000$ & $400-600$ & Including outer coastal arca \\
\hline NW coast & $2,000-3,000$ & $100-200$ & Cormmon eiders assumed \\
\hline Vaigat coast & $500-1,000$ & $1(x)-200)$ & Assumed \\
\hline Total & $15.400-20.100$ & $3,200-4,800$ & \\
\hline
\end{tabular}


(Abraham \& Finney 1986), and the overall population trends are unknown. Aerial surveys covering the entire Disko Bay region should be made to obtain a more complete picture of the autumn distribution of eiders in the region. The surveys should be carried out in early September, when the moult migration of king eiders cease.

Acknowledgements. - I wish to thank the crew of the Arctic Station's research vessel PORSILD. H.-E. Jensen took part in the field work in the summer of 1991 and T. K. Christensen in the autumn of 1992; H. Jensen, E. Knudsen, B. Mortensen, S. M. Nielsen, L. Skytte and F. Steffens provided information on eiders, my thanks are due to them all. J. Fjeldså and two anonymous referees are thanked for criticism of the manuscript, and R. M. Kristensen for various kinds of help. The study was supported financially by the Commission for Scientific Research in Greenland (grant No. 5.111/23 0.234-91) and the Danish Natural Science Research Council (grant No. 11-8974).

\section{References}

Abraham, K. F. \& Finney, G. H. 1986: Eiders of the eastern Canadian Arctic. Pp. 55-73 in Reed, A. (ed.): Eider ducks in Canada. Canadian Wildlife Service Rep. Ser. No. 46. Ottawa. Boertmann, D. 1979: (Ornithological observations in West Greenland, 1972-77). Dansk Orn. Foren. Tidsskr. 73, 171176. (English summary).

Cramp, S. \& Simmons, K. E. L. (cds.) 1977: Handbook of the birds of Europe, the Middle East, and North Africa: The birds of the Western Palearctic. Vol. I. Oxford University Press, Oxford and New York. 722 pp.

Frimer. O. in press: Autumn arrival and moult in King Eiders Somateria spectabilis at Disko, West Greenland. Arctic.

Frimer, O. \& Nielsen, S. M. 1990: Bird observations in Aqajarua-Sullorsuaq, Disko, West Greenland, 1989. Dansk Orn. Foren. Tidsskr. 84, 151-158.

Salomonsen, F. 1967: Fuglene på Grønland. Rhodos, København. $341 \mathrm{pp}$.

Salomonsen, F. 1968: The moult migration. Wildfowl 19.5-24. Salomonsen, F. (ed.) 1990: Grønlands fauna. (2nd cd.). Gyldendal, København. 464 pp. 